\title{
The Impact of Positive Law on Customary Law in Bialo Village, Gantarang District, Bulukumba Regency
}

\author{
Arahim 1), Auliah Andika Rukman 2), Mahendratul Ihwan ${ }^{3)}$ \\ Pancasila and Citizenship Education Study Program, Teaching and Education Faculty, Muhammadiyah \\ University of Makassar, Jl. Sultan Alauddin No.259, Makassar, Indonesia 1, 2,3) \\ arahim@unismuh.ac.id, auliahandikarukman@unismuh.ac.id, mahendratulihwan@unismuh.ac.id
}

\begin{abstract}
The main problem in this research is that the researcher wants to reveal the impact of positive law on customary law in Bialo Village, Gantarang District, Bulukumba Regency. This type of research is qualitative research which aims to determine the impact of positive law on customary law in Bialo Village, Gantarang District, Bulukumba Regency. The sampling technique was purposive sampling. The data collection techniques used were interviews and documentation. The results of this study indicate that the norms of customary law in the village of Bialo are still valid, including mappatabe, tudang sipulung, marriage, the relationship between humans and God, humans and nature, and humans and humans, boundaries of youth interactions, and customary sanctions. This situation is when we understand in detail. Basically, positive law is a law that binds in general or binds society as a whole. So that the implementation should not conflict with the norms that live in society. Norms that live in society in general can be concluded as a law that lives in the community or customary law so that researchers can conclude that positive law has good and bad impacts on customary law in Bialo Village, Gantarang District, Bulukumba Regency.
\end{abstract}

Keywords: Impact, Positive Law and Customary Law

\begin{abstract}
Abstrak. Masalah utama dalam penelitian ini adalah peneliti ingin mengungkap dampak hukum Positif terhadap hukum adat di Desa Bialo Kecamatan Gantarang Kabupaten Bulukumba. Jenis penelitian ini adalah penelitian kualitatif yang bertujuan untuk mengetahui Dampak hukum positif terhadap hukum adat di Desa Bialo Kecamatan Gantarang Kabupaten Bulukumba. Teknik pengambilan sampel yaitu Purposive Sampling. Teknik pengumpulan data yang digunakan adalah wawancara dan dokumentasi. Hasil penelitian ini menunjukkan bahwa Norma-norma hukum adat di desa Bialo masih berlaku di antaranya yaitu mappatabe, tudang sipulung, pernikahan, hubungan antara manusia dengan tuhan, manusia dengan alam, dan manusia dengan manusia, batasan pergaulan muda-mudi, dan sanksi adat. Keadaan tersebut bila kita memahami secara rinci Pada dasarnya hukum positif adalah hukum yang mengikat secara umum atau mengikat masyarakat pada keseluruhannya. Sehingga dalam pelaksanaan tidak boleh bertentangan dengan norma - norma yang hidup dalam masyarakat. Norma norma yang hidup dalam masyarakat secara umum dapat disimpulkan sebagai suatu hukum yang hidup dalam masyarakat atau hukum adat sehingga peneliti dapat mengambil kesimpulan bahwa hukum positif memberikan dampak yang baik dan buruk bagi hukum adat di Desa Bialo Kecamatan Gantarang Kabupaten Bulukumba.
\end{abstract}

Kata Kunci: Dampak, Hukum Positif dan Hukum Adat 


\section{INTRODUCTION}

Indonesia is a country based on positive law, meaning that the applicable law in Indonesia is based on the Pancasila rules, the constitution, and the applicable laws. Even though it adheres to a positive legal system, it cannot be denied that Indonesia is a country consisting of various ethnicities, races, ethnicities, clans and religions. Where the diversity of ethnicities, customs, races, and religions has influenced people's views of life and actions in solving problems they have been facing, including legal issues.

The laws that apply in Indonesia, both from western law, Islamic law, to customary law, clearly illustrate the diversity of laws that apply in Indonesia. That is the ideal situation, because in reality it is not always the case. This system of values is the core of the cultural system of a society, especially the spiritual aspects of the cultural system. In essence, law is a concretization of a system of values, especially the legal values of a society. (Soerjono Soekanto and Solaeman B. Taneko, 2002: 337).

So, Soerjono Soekanto and Solaeman B. Taneko describe the diversity of sources of law adopted by Indonesia and these value systems, which are the core of a society's cultural system, especially the spiritual aspects of that cultural system. From the diversity of laws, here the author will explore the existing customary laws in Indonesia, especially the customary laws in Bialo Village, Gantarang District, Bulukumba Regency.

Customary law as a law that lives and grows in society, law and society cannot be separated because the law appears with the community in accordance with the term that says "ubi societas ibi ius", where there is a community there is law. Therefore, customary law is a concrete form of social and cultural values. (Dewi Wulansari, 2014: 4)

Customary law is a law that is largely unwritten, but its values exist and apply in the lives of indigenous peoples who enforce these customary laws. Customary law applies in a limited scope, namely only applies to customary communities where the customary law lives or exists, and this situation allows that each customary community can have customary laws that differ from one another.

Actions disturbing the balance of society are defined as actions that are contrary to appropriateness, harmony, order, security, sense of justice, and legal awareness of the community concerned, which has been agreed by the community, whether it is the result of an act of a person or the customary ruler himself. Because it grows and develops based on the community's agreement on the values of propriety, it can be said that customary law is a living law and will continue to live as long as there are cultural people, and it cannot be abolished by legislation.

Customary law as positive law has specific characteristics, namely; Customary 
law is a law that is largely unwritten, but its values exist and apply in the lives of the customary communities that enforce the customary law. Customary law applies in a limited scope, namely only applies to customary communities where the customary law lives or exists. and this situation allows that each customary community can have customary laws that are different from one another. (Soekanto, 1985: 2)

Based on the background that has been described previously, it appears that positive law and customary law influence each other. But what's interesting is how is the news from customary law today after the implementation of positive law in Indonesia.

\section{RESEARCH METHODS}

In this study the authors used descriptive qualitative research. In qualitative research, data collection is not guided by theory, but is guided by facts found in the field. Therefore, the data analysis carried out is inductive based on the facts found and then it can be constructed into hypotheses and theories. Qualitative approaches do not rely on evidence based on systematic logic, number principles or statistical methods of actual speech, cues and other social actions are mental ingredients for qualitative analysis. This research is geographically located in Bialo Village, Gantarang District, Bulukumba Regency, South Sulawesi Province. This location was chosen because the research location is the hometown of the researcher and to make it easier to get information about the Impact of Positive Laws on Customary Law in Bialo Village, Gantarang District, Bulukumba Regency. The informants in this study were the Bulukumba Regional Government, the Bialo Village Government, Customary Law Experts, and the Bialo Village Community. The data collection process used purposive sampling technique. Purposive Sampling is a technique of collecting data source informants with certain considerations. At the data collection stage, researchers used data collection techniques used to obtain primary data (data obtained directly from the source) and secondary data (data obtained indirectly from the source) through interviews, observation, documentation and questionnaires. In this study using qualitative descriptive analysis techniques. The data validity technique in this study can be explained as follows:

1. Triangulation of sources, to test the credibility of the data is done by checking the data that has been obtained through several sources.

2. Technical triangulation, to test the credibility of the data is done by checking the data to the same source with different techniques.

3. Time triangulation, to test the credibility of the data can be done by checking with interviews, observations or other techniques in different times or situations. 


\section{DISCUSSION}

Customary Law Norms That Still Apply In Bialo Village, Gantarang District, Bulukumba Regency

Bialo Village is one of several villages in Bulukumba Regency that still applies customary rules or customary norms. Customary law has existed long before the invaders entered Indonesia and is valid until today.

The application of customary norms to date is an effort to protect and preserve the culture of Bialo Village against the threat of globalization and modernization. In addition, through the application of customary law norms, the community is expected to maintain relationships between people. This creates a village environment that adheres to the customs and habits of the Indonesian people, especially in Bialo Village.

Some of the efforts that have been made by the Bialo Village government in preserving customary law by inviting the community to traditional customs, for example in agriculture and marriage. The Village Government supervises the village community by taking into account the needs of the community in its application.

In making it easier for the author to analyze the customary norms that still apply in Bialo Village, Gantarang District, Bulukumba Regency, the author uses a policy theory approach. Policy (KBBI) is defined as a series of conceptual principles that outline and base plans for the implementation of a job, leadership, and how to act a statement of ideals, goals, principles and guidelines for management in achieving goals.

Leo Agustino (2008) defines policy as a series of actions / activities proposed by a person, group or government in a certain environment where there is an implementation of the policy proposal in order to achieve certain goals. This opinion also shows that policy ideas involve behavior that has goals and objectives, policies must show what is actually done rather than what is proposed in some activities on a problem.

\section{The Impact of Positive Law on Customary} Law in Bialo Village, Gantarang District, Bulukumba Regency

Law as a rule that regulates life together that must be obeyed and binds all citizens. Each violation will be sanctioned according to the weight of the violation committed and imposed in front of the community by the institution that has the task of imposing sanctions. In implementing law or policy, it must be accompanied by mutual synergy between the rules and the community itself. In other words, the rules that have been made should be a benchmark for every individual in their behavior, but if one of them does not synergize with these rules, it will give the rule a gap.

Positive law has a good and bad impact on customary law. Customary law is a 
source of positive law itself, but in its implementation in society, customary law is not really concerned with the existence of positive law.

The government as an important element in a country is needed to support the synergy of regulations. Likewise with the rules that will be designed for the future, not by prioritizing the middle and upper class. On the other hand, positive law clearly discusses the position of customary law as a reference for making statutory rules.

Every study requires a clear starting point or basis for thinking in solving a problem. For this reason, it is necessary to develop a theoretical basis that contains the main points of thought in describing the problems to be faced and makes it easier for us to find solutions to existing problems. In studying a problem, a theory that is a unit of analysis is needed to solve the problem with what is raised as a problem.

In examining this, the researcher uses the theory of perception where in language, the word perception comes from the English language Perception which means sight, feeling, and capture. Meanwhile, in the complete dictionary of popular Indonesian, perception has the meaning as a response to something seen or heard, or it can also mean the process of observing an object using the five senses. In the dictionary of terms of counseling and therapy, perception is defined as something that refers to a single awareness that arises from the sensing process when a stimulus appears.

We can know policies that are not synergized from the existing social reality from two views, namely the policy and the individual who is given the policy. In assessing a problem when we relate to perceptions how the impact of positive law on customary law in Bialo Village, Gantarang District, Bulukumba Regency, which is in accordance with what was discussed by the researcher, it can be said how an individual can express his opinion and be open to each other when perceiving in accordance with what he feels or the formation of perceptions begins with observations through the process of seeing, hearing, touching, feeling, and receiving something which then a person selects, organizes and interprets the information it receives into a meaningful picture.

The occurrence of this observation is influenced by past experiences and a person's attitude from the individual. And usually this perception only applies to himself and not to others. In addition, this perception does not last a lifetime can change according to the development of experiences, changes in needs, and attitudes of a person, both men and women according to the theory of perception used, it can be said that it answers itself, Philip Kotler (1993: 219) how someone selects, arranges and interprets input information to create a meaningful overall picture because when we interview we do each of the perceptions that 
come out is a characteristic of each source who applies these perceptions where this perception is an individual process to select, organize and interpret information inputs and experiences and then interpret them to create a meaningful overall picture. Perception is "how we see the world around us". Formally, perception can be defined as a process, by means of a person selecting, organizing, and interpreting the stimulus in a meaningful and comprehensive world picture. Perception is a process by which individuals organize and interpret their sensory impressions to give meaning to their environment.

The offers that have been given or the perceptions they have conveyed from the results of the interview are how the theory works to get the results of what the informants we met as informants, however, this informant, we as researchers have examined well, which are the results of the interview which can be used as a reference for the results of this discussion which applies triangulation to determine the results of interviews based on the theory of perception. Basically, the theory as a unit of analysis and techniques for obtaining data have been adjusted to obtain the desired results for this study.

\section{CONCLUSION}

1. The application of customary norms has been sinking so far that customary rules which can be said to be the identity of a region will gradually disappear. As an effort to protect and preserve the culture of Bialo Village against the threat of globalization and modernization through the application of customary law norms, the community is expected to maintain relationships between people. This creates a village environment that adheres to the customs and habits of the Indonesian people, especially in Bialo Village.

2. Basically, positive law is a law that binds in general or binds the community as a whole. So that the implementation should not conflict with the norms that live in society. The norms that live in society in general can be concluded as a law that lives in society or customary law so that researchers can conclude that positive law has good and bad impacts, including:

a. The good impact of law is positive for customary law because the law is not created to contradict each other and does not contradict the norms prevailing in society.

b. The bad impact is that the values contained in customary rules / laws are no longer embedded in the daily life of the village community, now customary law is not much different from positive law because customary law is only in the minds of the village community but does not implement and explore the values contained. inside it. 


\section{REFERENCES}

[1] Artikel ini telah tayang di Kompas.com dengan judul "Ini Pasal dalam RKUHP yang Berpotensi Melemahkan Pemberantasan Korupsi",

https://nasional.kompas.com/read/2018/06/0 5/16492901/ini-pasal-dalam-rkuhp-yangberpotensi-melemahkan-pemberantasankorupsi. Penulis : Kristian Erdianto Editor : Bayu Galih Di akses pada tanggal 10 juli 2018

[2] Aturan Peralihan UUD 1945 Pasal 131 ayat 2 sub b. I,

[3] Aturan Peralihan UUD 1945 Pasal II

[4] Bachsan Mustafa .2003.Sistem Hukum Indonesia Terpadu. Citra Adiyta Bakti: Bandung

[5] Bushar Muhammad. 2002. Asas-Asas Hukum Adat Suatu Pengantar. Jakarta: Pradnya Paramita. hlm. 11

[6] Depdikbud, (2001). Kamus Besar Bahasa Indonesia. Jakarta.Balai Pustaka

[7] Dewi Wulansari. 2012. Hukum Adat Indonesia-Suatu Pengantar. PT Refika Aditama: Bandung. hlm. 15

[8] Dewi wulansari. 2014. Hukum Adat Indonesia Suatu Pengantar. Bandung. Refika Aditama. hlm. 4

[9] Djamarat Samosir. 2013. Hukum Adat Indonesia. Bandung. Nuansa Aulia. hlm.1

[10] Firdaus Muhammad Arwan. hakim dan Keadilan Masyarakat, http://badilag.net/data/artikel/hakim\%20 dan\%20keadilan\%20masyarakat.pdf. Diakses pada tanggal 10 Juli 2018 Pukul 18.00 WITA http://hukum-danumum.blogspot.com/2012/04/makalahsumber-dan-asahukum-adat.html, diakses pada tanggal 30 Januari 2014, Pukul 15.35 Wita. Generated by Foxit PDF Creator (C) Foxit Software http://www.foxitsoftware.com For evaluation only. Diakses Pada Pukju. Diakses pada tanggal 04 April 2018 Pukul 22.00 WITA

[11] Hilman Hadikusuma. 1979. Hukum Pidana Adat. Bandung: Alumni.
[12] I Gde Pantja Astawa dan Suprin Na'a. 2008.Memahami Ilmu Negara dan Teori Negara.Bandung.PT Refika Aditama

[13] I Gde Pantja Astawa, S.H, M.H. 2008. dinamika hukum dan ilmu perundangundangan di Indonesia. PT alumni: Bandung

[14] Jimly Asshiddiqie. penegakan Hukum. http://www.jimly.com. Di akses pada tanggal 20 Februari 2018 Pukul 20.30 WITA

[15] Konstitusi Republik Indonesia Serikat (RIS)

[16] Made Somya Putra. Pengaturan Kesatuan Masyarakat Hukum Adat secara internasional, nasional dan di Balihttps://lawyersinbali.wordpress.com/2 011/10/06/pengaturan-kesatuan-masyarakathukum-adat-secara-internasional-nasionaldan-di-bali/. Diakses pada tanggal 04 April 2018 Pukul 21.09 WITA

[17] Mardjono 2009. Menyelaraskan Pembaruan Hukum.JKomisi Hukum Nasional RI.Jakarta.

[18] Marjdono Reksodipoetro. 2010. SPP (Peran Penegak Hukum) dikutip dari Romli Atmasasmita, Sistem Peradilam Pidana Kontemporer. Kencana Prenadia Group: Jakarta. hlm. 3

[19] Moh. Kusnadi, S.H, Harmaily Ibrahim, S.H. 1980. Pengantar Hukum Tata Negara Indonesia. Jakarta. Fakultas Studi Hukum Tata Negara Universitas Indonesia dan C.V. "Sinar Bakti"

[20] Nurdiansah. 2014 Skripsi Pemilihan Dan Peranan Kepala Adat (Ammatoa) Dalam Masyarakat Hukum Adat Kajang Dalam. http://repository.unhas.ac.id/bitstream/handle /123456789/11014/SKRIPSI\%20LENGKAP -PERDATANURDIANSAH.pdf?sequence $=1$. Diakses pada tanggal 04 April 2018 Pukul 23.50 WITA

[21] Pasal 13 ayat (3) Zelfbestuurs-Regelen 1938, 1938, dan 1939 Nomor 529 dan didalam “ Lange Contracten".

[22] Pasal 131 ayat (2) sub b Indische Staatstregeling

[23] Pasal 3 S. 1932 Nomor 80 
[24] Pasal 3a ROS. 1847 Nomor 23 Jo 1848 Nomor 47

[25] Prof. Dr. H. Dedi Ismatullah, M.Hum. 2009. Hukum Tata Negara. CV Pustaka Setia: Bandung

[26] R. Soepomo. 2007. Bab-bab Tentang Hukum Adat (Cetakan ke-17, Jakarta: PT. Pradnya Paramita. hlm 5

[27] RKUHP Pasal 1 ayat (1)

[28] RKUHP Pasal 2 ayat (1) dan (2)

[29] Rocky Marbun. 2013. Restorative Justice Sebagai alternatif Sistem Pemidanaan Masa Depan https://forumduniahukumblogku.wordpress.c om .diakses tanggal 20 Februari 2018 Pukul 22.45 WITA

[30] Setiady, Tholib Intusari. 2008. Intisari hukum adat Indonesia dalam kajian kepustakaan. Alfabeta. Bandung

[31] Soekanto. 1985. Meninjau Hukum Adat Indonesia. Edisi Ketiga. CV. Rajawali: Jakarta. hlm. 2

[32] Soerjono Soekanto, Solaeman B. Taneko. 2002. Hukum Adat Indonesia. PT Raja Grafindo Persada. Jakarta

[33] Soerjono Soekanto. 2002. Hukum Adat Indonesia. PT RajaGrafindo: Jakarta. hlm.5960

[34] Soleman B. Taneko. 1990. Hukum adat: suatu pengantar awal dan prediksi masa mendatang. Rajawali: Jakarta,

[35] Sugiyono. 2012. Metode Penelitian Kuantitatif Kualitatif dan $R \& D$. CV Alfabeta. Bandung

[36] Susanto Astrid. 2011. Komunikasi Dalam Teori Dan Praktek. Bandung : Penerbit Bina Cipta

[37] Suyanto, Bangong. 2005. Metode Penelitian Sosial: Berbagai Alternatif Pendekatan. Jakarta : Prenada Media
[38] Tolib Setiady. 2008. Intisari Hukum Adat Indonesia (Dalam Kajian Kepustakaan. Cetakan kedua. Alfabeta: Bandung

[39] Undang-Undang Darurat Nomor 1 Tahun1951 L.N Pasal 5 Ayat 3 sub b

[40] Undang-Undang Dasar 1945 Pasal 1 ayat (3)

[41] Undang-Undang Dasar 1945 pasal 18B ayat (2)

[42] UU No. 4 Tahun 2004 Tentang Kekuasaan Kehakiman 